\title{
Relationship between Occupation and Mother's Parity Status with Attitude towards Breastfeeding
}

\author{
Ramadhan Rifandy Widodo ${ }^{1}$, Tantut Susanto ${ }^{2 *}$, Latifa Aini Susumaningrum ${ }^{3}$ \\ ${ }^{1}$ Undergraduate Student, Faculty of Nursing, University of Jember, Jember, Indonesia. \\ ${ }^{2,3}$ Department of Community, Family, and Geriatric Nursing, Faculty of Nursing, University of Jember, \\ Jember, Indonesia. \\ *Corresponding Email: tantut_s.psik@unej.ac.id
}

\begin{abstract}
ARTICLE INFO
HOW TO CITED:

Widodo, R. R., Susanto, T., Susumaningrum, L.A. (2019). Relationship between Occupation and Mother's Parity Status with Attitude towards Breastfeeding. Jurrnal Pendidikan Keperawatan Indonesia 5(2), p. 105-113
\end{abstract}

DOI:

10.17509/jpki.v5i2.19045

\section{ARTICLE HISTORY:}

Accepted

December 11, 2019

Revised

December 22, 2019

Published

December 31, 2019

\begin{abstract}
A B S T R A C T
Double roles for working mothers caused stress which effects on their attitude towards breastfeeding practice. The objective of this study was to identify the correlation between mother's employment and parity and attitudes towards breastfeeding among mothers in Panti district, Jember regency. A crosssectional study was conducted among 273 mothers who have infants $0-6$ months using stratified random sampling. Respondents' characteristics and attitudes towards breastfeeding were measured using a questionnaire. A chisquare test was used to analyze the data. The results showed most of the mother was housewives $(80,2 \%)$, most of the mother were multipara $(64,5 \%)$ and most of the respondents have sufficient attitudes towards breastfeeding $(90,8 \%)$. There were no relationship between mother's employment and attitudes towards breastfeeding $\left(\chi^{2}=2,089 ; \mathrm{p}\right.$-value $\left.=0,352\right)$. However, there were significant relationship between maternal's parity and attitudes towards breastfeeding $(\chi 2=14,050 ; p$-value $=0,001)$. This study showed there was no relationship between the mother's employment and attitudes towards breastfeeding, although maternal's parity showed different results. Therefore, family planning program should be improved correctly to support mothers breastfeed their babies until the six month age to achieve exclusive breastfeeding practice.
\end{abstract}

Keywords: attitudes towards breastfeeding, mother employment, parity

\section{A B S T R A K}

Peran ganda pada ibu yang bekerja rawan menimbulkan stress yang dapat mempengaruhi pembentukan sikap ibu terutama sikap pemberian ASI, dimana sikap merupakan salah satu faktor penting yang mendorong keberhasilan pemberian ASI. Penelitian ini bertujuan mengidentifikasi hubungan pekerjaan dan status paritas ibu dengan sikap pemberian ASI (Air Susu Ibu) pada bayi usia 0-6 bulan di Kecamatan Panti Kabupaten Jember. Penelitian dengan desain cross sectional dilakukan pada 273 ibu yang memiliki bayi usia 0-6 bulan dengan stratified random sampling. Kuesioner digunakan untuk mengidentifikasi karakteristik responden dan sikap ibu dalam pemberian ASI eksklusif. Chi-square test digunakan untuk menjawab tujuan penelitian ini. Hasil penelitian menunjukkan sebagian besar pekerjaan ibu adalah ibu rumah tangga (80,2\%) dan sebagian besar ibu memiliki sikap pemberian ASI yang cukup $(90,8 \%)$. Analisis bivariat menunjukkan tidak terdapat hubungan antara 
pekerjaan ibu dengan sikap pemberian ASI ( $\chi 2=2,089$; $p$-value=0,352). Akan tetapi teridentifikasi bahwa status paritas ibu berhubungan dengan sikap pemberian ASI $(\chi 2=14,050 ;$-value =0,001). Dapat disimpulkan dari penelitian ini bahwa pekerjaan ibu tidak berhubungan dengan sikap pemberian ASI, tetapi status paritas ibu berhubungan dengan sikap pemberian ASI. Program KB (Keluarga Berencana) perlu ditingkatkan dengan tujuan mendorong ibu memberikan ASI kepada anaknya sesuai usia yang ditentukan.

Kata kunci: pekerjaan ibu, status paritas, sikap pemberian ASI

\section{INTRODUCTION}

The rate of breastfeeding in infants aged $0-5$ months in Indonesia is still quite low at $37.3 \%$, meanwhile, in East Java, it was $40 \%$ (Ministry of Health Indonesia, 2018). The most influential factor that can affect exclusive breastfeeding is the mother's occupation in sociodemographic factors (Balogun, Dagvadorj, Anigo, Ota, \& Sasaki, 2015). A working mother is becoming a trend in Indonesia, as evidenced by the high for occupational women at $55.44 \%$ (BPS Statistics Indonesia, 2018). Meanwhile, according to UU No. 13 Th. 2003 concerning working time in Indonesia, ranging from 7 to 8 hours per day. According to the research from Dachew \& Bifftu (2014), that condition can make it possible for mothers who work and have babies aged 0-6 months to be at risk of not being able to breastfeed their babies exclusively.

Housewives who have jobs outside the house certainly also have a dual role that must be carried out at the same time, this double role is prone to cause conflict, especially in working couples who have children under 18 years and in working mothers have various pressures in their work affairs and this situation can affect breastmilk production (Handayani, 2013; Hardiani, 2017). The dual role possessed by working mothers can be stressful because of two responsibilities that must be carried out at the same time (Friedman, Bowden, \& Jones, 2010). Stress and role strain that occurs often arises in a mother who is caused by work demands and responsibilities as a woman in the family (Friedman et al., 2010). Besides, that frustration and stress towards an object can influence the formation of attitudes towards the object (Azwar, 2016). A study found that mothers who didn't stress while breastfeeding was more likely to continue breastfeeding than mothers who were stressed (Susanto \& Rahmawati, 2015).

The most influenced factor that can affect success of breastfeeding for infants is attitude, as in a study which states that attitude hold an important role in breastfeeding by mothers to their babies, where mothers who have good or positive attitudes tend to breastfeed their babies well whereas mothers who were not breastfeeding their children tend to have bad or negative attitudes (Safdar, Jabeen, Kousar, Shahzadi, \& Gilani, 2017; Vijayalakshmi, Susheela, \& Mythili, 2015). Meanwhile, for parity status, research by Cotelo, Movilla-Fernández, Pita-García, \& Novío (2018) found that there were differences attitudes between primiparous and multiparous mothers. According to research from Balogun, Dagvadorj, Anigo, Ota, \& Sasaki (2015) that among the factors that influence breastfeeding, maternal's occupation is the dominant factor that can influence breastfeeding in infants 0-6 months.

Based on these descriptions, researchers are interested in further study and analysis of the mother's attitude in breastfeeding infants aged 0 6 months and their relationship with the mother's work. This study was conducted to identify the relationship between work and mother's attitude in breastfeeding infants aged 0-6 months in the Panti district of Jember. Besides, it also examined the status of maternal parity and its relationship with the attitude of breastfeeding.

\section{METHODS}

This research is quantitative with descriptive correlational and uses a cross-sectional design. The population using mothers who have babies aged 0-6 months in Panti District in May 
2019 was 378 people. Then the researchers count the number of samples needed with a confidence level of $95 \%$ and a precision error of $10 \%$. The proportion of exclusive breastfeeding in Indonesia is $35.74 \%$ ( Ministry of Health, Indonesia, 2014). Then the researchers get a sample needed in this study as many as 320 respondents. The sampling technique in this study uses a probability sampling technique with stratified random sampling. Inclusion criteria for mothers in this study are mothers who have infants aged 0-6 months and mothers who have work or not, while the exclusion criteria are mothers who work outside the city or abroad and mothers who can't breastfeed because they have certain diseases. The inclusion criteria for infants are infants aged 0-6 months and raised by biological mothers, while the exclusion criteria are infants with galactosemia or other congenital abnormalities and infants who were sick so that they couldn't be breastfed.

Data collection of respondents in this study done by using stratified random sampling techniques. The researcher calculated the samples needed in the study by stratification each village in the Panti District. Then the researchers calculated the location of the number of samples needed in each village proportionally based on the total population of each village multiplied by the number of samples divided by the number and obtained the required sample results in each village of 320 respondents. After counting and getting the results, the researchers then collected data related to the area and the identity of the respondents with the inclusion criteria determined by the researcher. The researcher conducted the study by visiting each respondent's house that had been obtained from the local midwife. After the researchers met the respondent then gave informed consent as a form of approval to become a respondent and followed by an explanation of the intent and purpose, informed research consent and how to fill out the questionnaire to the respondent. Then the questionnaire is filled directly by the respondent with the assistance of the researcher and after completing the questionnaire, the respondent returns it to the researcher, then the researcher checks the completeness of the questionnaire filled out by the respondent. This research takes 10 to 15 minutes for each respondent. From several sample counts, 273 people were collected, with 47 dropping out of this study due to relocation, unwillingness to become respondents, and the baby died.

The data collection tools in this research were used questionnaires. There are two questionnaires; they were questionnaires about the mother's demographic, social data and the questionnaire about the mother's attitudes in breastfeeding. The first questionnaire is about the socio-demographic status of the mother which is used to see the characteristics of the respondents. The mother's occupation became the main focus of this questionnaire because it was an independent variable in this study. The questionnaire about the characteristics of the respondents contained about the name, age, address, last education, occupation, and working time of the mother in one day, parity status, number of children, and breastfeeding.

The second questionnaire is about the attitude of the mother towards breastfeeding used to measure the attitude of the mother in breastfeeding to her baby; the questionnaire used was the Maternal Attitudes Towards Breastfeeding Questionnaire adaptation from previous studies (Mohamed, Ochola, \& Owino, 2012). This questionnaire contains 11 statements about the mother's attitude in giving breastmilk to her baby on a Likert scale. The 11 statements listed on the questionnaire, 7 of them are positive statements and 4 of them are negative statements. Every positive statement gets three value and negative statement gets 0 value, which means that if the respondent agrees with a positive statement, then it is worth 3 and 0 if it does not agree. The final result score is $\leq 20$. It means that the mother has fewer attitudes, while the total score 21-30 means that the mother has sufficient attitudes, and the total score $\geq$ of 31 ; it means that the mother has good attitudes. The validity and reliability of the questionnaire were conducted in this study, the alpha Cronbach value obtained from the Maternal Attitudes Towards Breastfeeding Questionnaire was 0.89 and when 
compared with the reliability value of the previous researcher which was 0.85 (Mohamed et al., 2012). Then it can be said that this questionnaire is reliable for use as a measurement tool in this study.

The final data of this study presented in a percentage when categorical data, in mean and standard deviations when numeric data if it has normal data distribution, in medians and percentiles if it has normal data distribution, and the Kolmogorov-Smirnov test are used in this study to see the data distribution data analysis. Bivariate analysis was used in this study is Chi-Square to find out whether there is a relationship between occupation and parity status of mothers with breastfeeding attitudes, then Mann-Whitney to find out whether there is a relationship between the occupation of mothers and each item questionnaire statement of breastfeeding attitude. Data analysis was performed using SPSS 16 software applications.

This research was conducted in an ethics test at the Ethics Commission of the Faculty of Dentistry, the University of Jember with certificate number 365 /UN25.8 / KEPK / DL / 2019, and it was stated that this research could be carried out by paying attention to the principles in research ethics. The researcher then obtained ethical and administrative approval from the Jember Political Nations Unity and Politics Agency and the Jember Public Health Office and the Panti Health Center.

\section{RESULTS}

\section{Characteristics of Participants}

Based on table 1 it can be seen that the characteristics of mothers, most of the mothers working as housewives are 219 participants $(80.2 \%)$ and mothers who have job are 54 participants (19.8\%) with 34 participant (12.5\%) work less than 8 hours a day and 20 participant (7.3\%) work more than 8 hours a day, and more than half of the participants are multiparous mothers 176 participants $(64.5 \%)$.

Mother's Attitude towards Breastfeeding

Based on table 2 it can be seen that the median value of the mother's attitude score in breastfeeding from 273 mothers in Panti District was 25 with a range of percentiles $25-75$, which it can be categorized according to the attitude of breastfeeding is said to have sufficient attitudes (Mohamed et al ., 2012).

Based on Figure 1, it can be seen that most of the participants have an adequate breastfeeding attitude, which is $90.8 \%$ or a total of 248 participants.

\section{Relationship between Mother's Occupation and Attitudes towards Breastfeeding}

Table 3 shows that there was no difference between the attitude of breastfeeding of housewives mother and working mothers, as evidenced by the Chi-Square test $(\chi 2=2.089$; $p$ value $=0.352$ ), so it can be concluded that there is no relationship between working mothers and mothers' attitudes towards breastfeeding.

\section{Relationship between Characteristics and At- titudes towards Breastfeeding}

Based on table 4 it can be seen that from the characteristics of the respondents if they were related to the attitude of breastfeeding there is no relationship, except for maternal parity status as evidenced by the Chi-Square test ( $\mathrm{p}$-value = $0.001<0.05)$ so it can be concluded that there was a relationship between maternal parity status and breastfeeding attitudes.

\section{DISCUSSION \\ Respondent's Characteristic}

This study found that most of the participants are housewives. The two groups of participants (working mother and housewives) both of them had sufficient attitude, so it can be concluded that no differences were found between the two groups of participants. The other study also showed that both working mothers and housewives had sufficient attitudes, and no significant differences were found, similarly maternal age also had no relationship with the attitude towards breastfeeding (Cotelo et al., 2018). Behavior can be influenced by emotional factors such as stress, and also be formed through personal experience and information received (Azwar, 2016). So it can be concluded that 
Widodo, R. R., Susanto, T., Susumaningrum, L.A.| Relationship between Occupation and Mother 's Parity Status with Attitude...

Table 1. Characteristics of Participants $(n=273)$

\begin{tabular}{|c|c|c|}
\hline Characteristics of Respondents & Child & Maternal \\
\hline $\begin{array}{l}\text { Age } \\
\text { Md (P25-P75) }\end{array}$ & $\begin{array}{l}\text { (months) } \\
4(3-5)\end{array}$ & $\begin{array}{l}\text { (years) } \\
27(23-32)\end{array}$ \\
\hline \multicolumn{3}{|l|}{ Maternal's Education } \\
\hline Illiterate & & $10(3,7 \%)$ \\
\hline Primary School & & $99(36,3 \%)$ \\
\hline Intermediate School & & $60(22 \%)$ \\
\hline High School & & $81(29,7 \%)$ \\
\hline Diploma & & $4(1,5 \%)$ \\
\hline \multicolumn{3}{|l|}{ Maternal's Occupation } \\
\hline Housewives & & $219(80,2 \%)$ \\
\hline Housemaid & & $1(0,4 \%)$ \\
\hline Midwife & & $1(0,4 \%)$ \\
\hline Teacher & & $17(6,2 \%)$ \\
\hline Shop Employees & & $6(2,2 \%)$ \\
\hline Tobacco Coolie & & $1(0,4 \%)$ \\
\hline Private Bussines & & $17(6,2 \%)$ \\
\hline Government Employees & & $4(1,5 \%)$ \\
\hline Nurse & & $1(0,4 \%)$ \\
\hline \multicolumn{3}{|l|}{ Work Time (in a single day) } \\
\hline Unemployed & & $219(80,2 \%)$ \\
\hline$<8$ hours & & $34(12,5 \%)$ \\
\hline$>8$ hours & & $20(7,3 \%)$ \\
\hline \multicolumn{3}{|l|}{ Parity Status } \\
\hline Primiparous & & $97(35,5 \%)$ \\
\hline Multiparous & & $176(64,5 \%)$ \\
\hline \multicolumn{3}{|l|}{ Child } \\
\hline 1 & & $97(35,5 \%)$ \\
\hline 2 & & $98(35,9 \%)$ \\
\hline 3 & & $63(23,1 \%)$ \\
\hline 4 & & $11(4 \%)$ \\
\hline 5 & & $4(1,5 \%$ \\
\hline \multicolumn{3}{|l|}{ Child } \\
\hline \multicolumn{3}{|l|}{1} \\
\hline \multicolumn{3}{|l|}{2} \\
\hline 3 & & $198(72,5 \%)$ \\
\hline 4 & & $75(27,5 \%)$ \\
\hline 5 & & \\
\hline
\end{tabular}


Widodo, R. R., Susanto, T., Susumaningrum, L.A. | Relationship between Occupation and Mother 's Parity Status with Attitude...

Table 2. Mother's Attitude towards Breastfeeding $(n=273)$

\begin{tabular}{cccc}
\hline Variable & $\mathrm{Md}\left(\mathrm{P}_{25}-\mathrm{P}_{75}\right)$ & $\mathrm{Z}$ & $\mathrm{p}$-value \\
\hline Attitude & $25(24-27)$ & 1,707 & 0,006 \\
\hline
\end{tabular}

Table 3. Relationship between Mother's Occupation and Attitudes towards Breastfeeding $(\mathrm{n}=\mathbf{2 7 3})$

\begin{tabular}{|c|c|c|c|c|}
\hline \multirow[b]{2}{*}{ Maternal's Occupation } & \multicolumn{3}{|c|}{ Attitudes towards Breastfeeding } & \multirow{2}{*}{$\begin{array}{c}\chi^{2} \\
\text { (p-value) }\end{array}$} \\
\hline & $\begin{array}{l}\text { Good } \\
\mathrm{n}(\%)\end{array}$ & $\begin{array}{l}\text { Sufficient } \\
\mathrm{n}(\%)\end{array}$ & $\begin{array}{l}\text { Low } \\
\mathrm{n}(\%)\end{array}$ & \\
\hline Housewives & $11(5 \%)$ & $199(90,9 \%)$ & $9(4,1 \%)$ & \multirow{2}{*}{$\begin{array}{c}2,089 \\
(0,352)\end{array}$} \\
\hline Working Mother & $1(1,9 \%)$ & $49(90,7 \%)$ & $4(7,4 \%)$ & \\
\hline
\end{tabular}

Table 4. Relationship between Characteristics and Attitudes towards Breastfeeding (n= 273)

\begin{tabular}{lc}
\hline Characteristics of Respondents & p-value \\
\hline Age & 0,758 \\
Maternal (years) & 0,591 \\
Child (months) & 0,742 \\
Maternal's Education & 0,352 \\
Maternal's Occupation & 0,687 \\
Work Time (in a single day) & 0,001 \\
Parity Status & 0,064 \\
Child & 0,469 \\
Breastfeeding & \\
\hline
\end{tabular}

\section{Attitudes towards Breastfeeding}

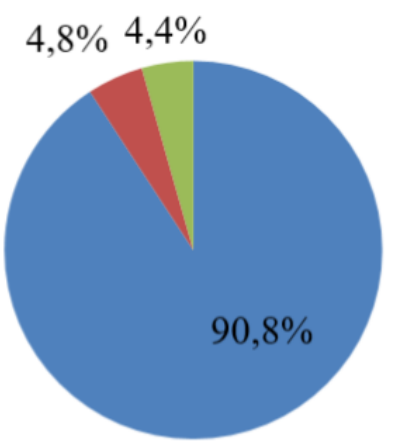

Sufficient

Low

Good

Figure 1. The proportion of Mother's Attitude towards Breastfeeding 
previous breastfeeding experience and knowledge about breastfeeding can influence the attitude of breastfeeding.

\section{Respondent's Attitude towards Breastfeeding}

The value of attitude towards breastfeeding from the participants shows that most of them have a sufficient attitude towards breastfeeding. The higher mother's education and mother's knowledge about breastfeeding, good breastfeeding skills and experience, older age, and high family income tend to have a stronger attitude to committed towards breastfeeding (Hamze, Carrick-Sen, Zhang, Liu, \& Mao, 2018). The results of this study have different findings; most breastfeeding attitudes were sufficient; maternal's education was relatively low with most the mothers have elementary school education level. Whereas the relationship between education levels shows that there was no significant relationship. This study shows that the level of education doesn't indicate a mother's attitude towards breastfeeding; the other study showed that the properly empowerment of family could increase the knowledge and attitudes towards breastfeeding (Hamze et al., 2018). Mothers with low levels of education may not necessarily have low breastfeeding attitudes; the knowledge about breastfeeding can be found anywhere, even for mothers who don't have an occupation or as housewives with proper family empowerment can increase knowledge and attitudes towards breastfeeding.

\section{Relationship between Occupation and Atti- tude towards Breastfeeding}

Based on the results of this study, we know that there is no relationship between maternal's occupation and maternal attitudes towards breastfeeding for infants aged 0-6 months in Panti District, Jember. The results of this study indicate that most mothers have adequate breastfeeding attitudes with no difference between working mothers and housewives. The other study from Hamze, Mao, \& Reifsnider (2019) shows the same result with this study, there was no difference between groups of mothers who don't have an occupation, working mothers, and mother's work time, and from those group also has a good breastfeeding attitudes. Although the mother's occupation and attitude towards breastfeeding are not related, this study found another result. There was a relationship between the characteristics of participants (maternal's parity status) with the attitude towards breastfeeding.

\section{Relationship between Parity Status and Atti- tude towards Breastfeeding}

The analysis of the relationship between characteristics of participants with the attitude towards breastfeeding showed that there was no significant relationship between the characteristics of participants and attitude towards breastfeeding except the maternal's parity status. This study has the same result as the other study that found parity status is related to the attitude towards breastfeeding; there was found a significant difference between primiparous and multiparous mothers on the breastfeeding attitude (Cotelo et al., 2018). Multiparous mother has better breastfeeding attitudes than primiparous mothers (Cotelo et al., 2018). The other study also found that better breastfeeding experience than a better attitude towards breastfeeding (Hamze et al., 2018). Multiparous mothers certainly have more experience and skills rather than primiparous mothers who have and caring for their first child, and this experience is an important asset for a mother to increase her commitment and attitude to breastfeed her baby.

The results of this study showed that there is no relationship between the mother's occupation with the attitude towards breastfeeding in Panti District, Jember. It can happen because most working mothers and housewives have sufficient breastfeeding attitudes. In this study, there was a relationship between maternal's parity status and maternal attitudes towards breastfeeding. This study allows that multiparous mothers who have cared for their children have better experience and skills so that they can encourage good breastfeeding attitudes towards multiparous mothers. The other study has the same result with research which showed that there were significant differences in breastfeeding attitudes between primiparous and multiparous mothers and knowledge about breastfeeding, breast- 
feeding skills and experience are important factors in improving maternal attitudes in breastfeeding (Cotelo, Movilla-Fernández, PitaGarcía, \& Novío, 2018; Hamze, Carrick-Sen, Zhang, Liu, \& Mao, 2018).

\section{CONCLUSION}

The results of this study indicate that there was no relationship between maternal's occupation and maternal attitudes towards breastfeeding, but there was a relationship between participant's characteristics, parity status of mothers, and maternal attitudes towards breastfeeding. Therefore support and exposure to information are needed for mothers who have babies, especially their first baby. Support from family and implementation of family planning can be applied to improve the achievement of exclusive breastfeeding, and it was expected that local

\section{REFERENCES}

Azwar, S. (2016). SIKAP MANUSIA: Teori dan Pengukurannya (2nd ed.). Yogyakarta: LIBERTY.

BPS Statistics Indonesia. Badan Pusat Statistik. (2018). Keadaan Angkatan Kerja di Indonesia Agustus 2018. Jakarta: Badan Pusat Statistik Indonesia.

Balogun, O. O., Dagvadorj, A., Anigo, K. M., Ota, E., \& Sasaki, S. (2015). Review Article Factors influencing breastfeeding exclusivity during the first 6 months of life in developing countries: a quantitative and qualitative systematic review. Maternal and Child $\mathrm{Nu}-$ trition, 1-19. https://doi.org/10.1111/ men. 12180

Cotelo, M. del C. S., Movilla-Fernández, M. J., Pita-García, P., \& Novío, S. (2018). Infant feeding attitudes and practices of Spanish low-risk expectant women using the IIFAS (Iowa infant feeding attitude scale). Nutrients, 10(4), 1-15. https://doi.org/10.3390/ nu 10040520

Dachew, B. A., \& Bifftu, B. B. (2014). Breastfeeding practice and associated factors among female nurses and midwives at North health workers, especially nurses could provide information to mothers who have babies aged 0-6 months about the benefits of exclusive breastfeeding for babies aged 0-6 months, how to breastfeed correctly, as well as the benefits of breastfeeding for mother and baby so that it is expected to increase the commitment and motivation of a mother in exclusively breastfeeding her child.

\section{ACKNOWLEDGEMENT}

The researcher would like thanks to the Family and Health Care Studies (FHCS) Research Group from the Department of Family, Community, and Gerontology of Nursing, Faculty of Nursing, University of Jember, for facilitating all parts from this research. The researcher also thanked the Panti Health Center and all respondents who participated in this study.

Gondar Zone, Northwest Ethiopia : a crosssectional institution based study. International Breastfeeding Journal, 9(11), 1-7.

Friedman, M. M., Bowden, V. R., \& Jones, E. G. (2010). Buku Ajar Keperawatan Keluarga: Riset, Teori, dan Praktik (5th ed.). Jakarta: Penerbit Buku Kedokteran EGC.

Hamze, L., Carrick-Sen, D., Zhang, Z., Liu, Y., \& Mao, J. (2018). Maternal attitude towards breastfeeding: A concept analysis. British Journal of Midwifery, 26(7), 462-469. https://doi.org/10.12968/bjom.2018.26.7.462

Hamze, L., Mao, J., \& Reifsnider, E. (2019). Knowledge and attitudes towards breastfeeding practices: A cross-sectional survey of postnatal mothers in China. Midwifery, 74, 68-75. https://doi.org/10.1016/ j.midw.2019.03.009

Handayani, A. (2013). Keseimbangan Kerja Keluarga pada Perempuan Bekerja: Tinjauan Teori Border. Buletin Psikologi, 21(2), 90-101.

Hardiani, R. S. (2017). Status Paritas dan Pekerjaan Ibu terhadap Pengeluaran ASI pada Ibu Menyusui 0-6 Bulan. NurseLine Journal, 2 (1), 44-51. 
Widodo, R. R., Susanto, T., Susumaningrum, L.A.| Relationship between Occupation and Mother 's Parity Status with Attitude...

Kementerian Kesehatan Republik Indonesia. (2014). InfoDatin, Situasi dan Analisis ASI Eksklusif. Pusat Data Dan Informasi Kementerian Kesehatan RI. https:// doi.org/10.1017/CBO9781107415324.004

Kementerian Kesehatan Republik Indonesia. (2018). HASIL UTAMA RISKESDAS 2018. Jakarta Selatan: Badan Penelitian dan Pengembangan Kesehatan Kementerian Kesehatan Republik Indonesia.

Mohamed, M. J., Ochola, S., \& Owino, V. O. (2012). Comparison of Knowledge, Attitudes, and Practices on Exclusive Breastfeeding Between Primiparous and Multiparous Mothers Attending Wajir District Hospital, Wajir County, Kenya. International Breastfeeding Journal, 13(11), 1-10. Retrieved from http://ir-library.ku.ac.ke/ bitstream/handle/123456789/17602/

comparison of knowledge attitude.pdf? sequence $=1 \&$ is Allowed $=\mathrm{y}$
Safdar, M., Jabeen, C., Kousar, R., Shahzadi, C., \& Gilani, D. S. A. (2017). The Assessment of Knowledge, Attitude, and Practices of Exclusive Breast Feeding Among Lactating Mothers: A Case of Children Hospital of Lahore, Pakistan. Saudi Journal of Medicine, 2(3), 76-84. https://doi.org/10.21276/ sjm. 2017

Susanto, T., \& Rahmawati, I. (2015). Relactation method for improving exclusive breastfeeding at Arjasa Community Health Center, sub-province Jember, East Java, Indonesia. The Malaysian Journal of Nursing, 6(2), 24-29.

Vijayalakshmi, P., Susheela, T., \& Mythili, D. (2015). Knowledge, attitudes, and breastfeeding practices of postnatal mothers: A cross-sectional survey. International Journal of Health Sciences, Qassim University, 9(4), 364-374. $\quad$ https:// doi.org/10.12816/0031226 